\title{
SILEX: a fast and inexpensive high-quality DNA extraction method suitable for multiple sequencing platforms and recalcitrant plant species
}

Santiago Vilanova ${ }^{{ }^{*}+} \mathbb{0}$, David Alonso ${ }^{1 \dagger}$, Pietro Gramazio² ${ }^{4}$ Mariola Plazas ${ }^{1}$, Edgar García-Fortea ${ }^{1}$, Paola Ferrante ${ }^{3}$, Maximilian Schmidt ${ }^{4}$, María José Díez ${ }^{1}$, Björn Usadel ${ }^{4,5}$, Giovanni Giuliano ${ }^{3}$ and Jaime Prohens ${ }^{1}$

\begin{abstract}
Background: The use of sequencing and genotyping platforms has undergone dramatic improvements, enabling the generation of a wealth of genomic information. Despite this progress, the availability of high-quality genomic DNA (gDNA) in sufficient concentrations is often a main limitation, especially for third-generation sequencing platforms. A variety of DNA extraction methods and commercial kits are available. However, many of these are costly and frequently give either low yield or low-quality DNA, inappropriate for next generation sequencing (NGS) platforms. Here, we describe a fast and inexpensive DNA extraction method (SILEX) applicable to a wide range of plant species and tissues.

Results: SILEX is a high-throughput DNA extraction protocol, based on the standard CTAB method with a DNA silica matrix recovery, which allows obtaining NGS-quality high molecular weight genomic plant DNA free of inhibitory compounds. SILEX was compared with a standard CTAB extraction protocol and a common commercial extraction kit in a variety of species, including recalcitrant ones, from different families. In comparison with the other methods, SILEX yielded DNA in higher concentrations and of higher quality. Manual extraction of 48 samples can be done in 96 min by one person at a cost of $0.12 € /$ sample of reagents and consumables. Hundreds of tomato gDNA samples obtained with either SILEX or the commercial kit were successfully genotyped with Single Primer Enrichment Technology (SPET) with the Illumina HiSeq 2500 platform. Furthermore, DNA extracted from Solanum elaeagnifolium using this protocol was assessed by Pulsed-field gel electrophoresis (PFGE), obtaining a suitable size ranges for most sequencing platforms that required high-molecular-weight DNA such as Nanopore or PacBio.

Conclusions: A high-throughput, fast and inexpensive DNA extraction protocol was developed and validated for a wide variety of plants and tissues. SILEX offers an easy, scalable, efficient and inexpensive way to extract DNA for various next-generation sequencing applications including SPET and Nanopore among others.
\end{abstract}

Keywords: DNA extraction, CTAB protocol, Silica matrix, Contaminant-free DNA, High-molecular-weight DNA, Nextgeneration sequencing, High-throughput genotyping, Recalcitrant species, SPET, Nanopore

\footnotetext{
*Correspondence: sanvina@upvnet.upv.es

† Santiago Vilanova and David Alonso contributed equally to this work ${ }^{1}$ Instituto de Conservación y Mejora de la Agrodiversidad Valenciana, Universitat Politècnica de València, Camino de Vera 14, 46022 Valencia, Spain

Full list of author information is available at the end of the article
}

\section{Background}

In the last decade, sequencing and genotyping technologies have become routine, allowing to generate a wealth of genomic information even in non-model plant species and neglected crops $[1,2]$. Nowadays, genome

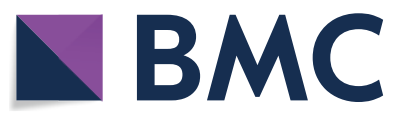

(c) The Author(s) 2020. This article is licensed under a Creative Commons Attribution 4.0 International License, which permits use, sharing, adaptation, distribution and reproduction in any medium or format, as long as you give appropriate credit to the original author(s) and the source, provide a link to the Creative Commons licence, and indicate if changes were made. The images or other third party material in this article are included in the article's Creative Commons licence, unless indicated otherwise in a credit line to the material. If material is not included in the article's Creative Commons licence and your intended use is not permitted by statutory regulation or exceeds the permitted use, you will need to obtain permission directly from the copyright holder. To view a copy of this licence, visit http://creativeco mmons.org/licenses/by/4.0/. The Creative Commons Public Domain Dedication waiver (http://creativecommons.org/publicdomain/ zero/1.0/) applies to the data made available in this article, unless otherwise stated in a credit line to the data. 
sequencing, as well as the most common high-throughput genotyping strategies, like Genotyping-by-Sequencing (GBS [3]), Restriction Associated DNA Sequencing (RADseq [4]) and Single Primer Enrichment Technology (SPET $[5,6]$ ), are conducted using next-generation sequencing (NGS) platforms. However, despite the advances, DNA quality is still a main bottleneck, mostly for the third-generation sequencing platforms where high-molecular-weight DNA free of contaminants is required [7]. Unlike bacteria and mammalian cells, fungi and plant cells are protected by rigid polysaccharide cell walls that hamper the extraction of unfragmented DNA [8]. Furthermore, plants produce a wide array of compounds and secondary metabolites (e.g., pigments, phenols, carbohydrates, waxes, among others) that tend to co-precipitate with the DNA and interfere with the subsequent enzymatic reactions [9].

So far, the CTAB DNA extraction protocol developed by Doyle and Doyle [10] is one of the most widely used by plant researchers. Several modifications of this protocol have been implemented in order to minimize contamination by other compounds of specific tissues of species [7, 11, 12]. These modifications, apart from being species or tissue-specific and frequently not removing completely interfering compounds, are time-consuming due to many handling steps, and thus are not suitable for highthroughput applications $[13,14]$.

Conversely, commercial kits based on silica matrices avoid many of these issues by optimizing the conditions in which only DNA can bind to the silica surface. Therefore, contaminants such as polysaccharides, polyphenols and proteins can be easily removed [15]. They also tend to be faster than the standard CTAB protocol, being the preferred option for sequencing studies in which many samples must be evaluated $[9,16]$. Usually, commercial kits rely on the reversible interaction between DNA and a silica or silicate support, either in the form of a filter membrane or of silica-coated magnetic particles $[17,18]$. The adsorption of DNA to the silica surface is facilitated by buffers with low $\mathrm{pH}$, high concentrations of chaotropic salts (such as guanidinium hydrochloride, guanidinium thiocyanate, or sodium iodide) and ethanol [19-22]. Under these conditions, the surface of the silica can interact with the negative surface of DNA via ionic interactions $[23,24]$. After several washes with high concentrations of ethanol to eliminate contaminants, DNA is generally eluted with water or TE at $\mathrm{pH}$ 8.0. At this higher $\mathrm{pH}$ value, the negatively charged silica surface and DNA repeal each other, releasing the DNA [25-27].

However, commercial kits are usually expensive, with reagent costs commonly ranging between 2 and 9 US\$ per sample $[8,28]$, and many times provide low yields, insufficient for some NGS applications [8, 29].
Furthermore, for some commercial kits, the DNA quality and quantity obtained in recalcitrant species is low [30-32]. DNA extraction methods relying on silica matrices and chaotropic salts have been reported [33-36]; however, chaotropic salts can inhibit subsequent enzymatic reactions which are essential for NGS applications [37-39].

In this study, we present a novel, fast and inexpensive DNA extraction protocol that combines the advantages of CTAB-based extraction coupled with a purification on a silica matrix. The new method was assessed on different species, including recalcitrant ones and different tissues. To test its suitability for different NGS applications, the method was compared with commercial kits for Single Primer Enrichment Technology (SPET) genotyping [6]. The method was also used to extract high-molecularweight DNA from a recalcitrant wild species (Solanum elaeagnifolium). The DNA obtained was successfully used to construct long insert size Nanopore libraries for a de novo genome assembly, which can be difficult for recalcitrant species [40], thus proving its suitability for third-generation sequencing platforms.

We demonstrate that this new method combines the advantages of commercial kits (high-quality DNA, fast and broad range of species spectrum) with those of a CTAB-based method (high yield and inexpensive) being suitable for routinely DNA screening and NGS platforms.

\section{Materials \\ Plant material}

To test our proposed protocol (hereafter named SILEX, for SILica matrix EXtraction), leaf and fruit tissue from non-recalcitrant species and leaf tissue from recalcitrant species was sampled for four different trials. In a first trial, leaf tissue from a total of 1860 accessions of tomato (S. lycopersicum) and its wild relatives was extracted to compare the quality, quantity and integrity of DNA extracted using SILEX and the commercial kit sbeadex maxi plant kit (hereafter SMP kit; LGC Genomics, Teddington, UK) for SPET genotyping. Extractions were performed on different days over several months.

In a second trial, in order to evaluate the appropriateness of SILEX in different plant tissues, $50 \mathrm{mg}$ of fresh and $30 \mathrm{mg}$ of lyophilized fruit tissue of tomato, eggplant (S. melongena) and pepper (Capsicum annuum) were extracted. The fruit tissue was collected, immediately frozen in liquid $\mathrm{N}_{2}$ and lyophilized In a third trial, the suitability of SILEX for DNA extraction in recalcitrant species was assessed using leaves tissue of six species, cassava (Manihot esculenta), grapevine (Vitis vinifera), loquat (Eriobotrya japonica), banana (Musa $\times$ paradisiaca), naranjillo (Solanum bonariense), and strawberry (Fragaria $\times$ ananassa), selected 
to represent a wide range of recalcitrant species presenting different contaminants and secondary metabolites that interfere with DNA extraction. Extractions from recalcitrant plants made by SILEX were compared with those carried out using the standard CTAB protocol [10] and the commercial SMP kit following the manufacturer's instructions. Finally, the suitability of SILEX to extract clean and high-molecular-weight DNA for third-generation sequencing was assessed in the silverleaf nightshade (S. elaeagnifolium), a wild relative of eggplant [41], that we selected for the difficulty to obtain contaminant-free DNA due to its high content in phenolics [42].

\section{Solutions, reagents and consumables}

- $2 \mathrm{ml}$ Sarstedt Microtube (https://www.sarstedt. com, Cat No. 72.691).

- $5 \mathrm{~mm}$ Glass beads (https://www.vwr.com, Cat No. MARI4901005).

- N-Cetyl- $N, N, N$-trimethylammonium bromide, CTAB (https://www.itwreagents.com, Cat No. A6284.0500).

- Polyvinylpyrrolidone, PVP-40 (https://www.sigma aldrich.com, Cat No. PVP40-500G).

- Ethylenediaminetetraacetic acid, EDTA (https:// www.itwreagents.com, Cat No. 131026.1210).

- Trizma ${ }^{\circledR}$ hydrochloride, Tris $\mathrm{HCl}$ (https://www. sigmaaldrich.com, Cat No. 93363-500G).

- Sodium Chloride (https://www.itwreagents.com, Cat No. 131659.1211).

- $\beta$-Mercaptoethanol (https://www.sigmaaldri ch.com, Cat No. M6250-100ML).

- RNase A (https://www.vwr.com, Cat No. NA-03).

- Chloroform Essent ${ }^{\circledR}$ (https://www.scharlab.com, Cat No. CL1981000).

- Isoamyl alcohol Essent ${ }^{\circledR}$ (https://www.scharlab. com, Cat No. AL02851000).

- Polyethylene Glycol 8000 (https://www.itwreagent s.com, Cat No. 146224.1211).

- Absolute Ethanol ExpertQ ${ }^{\circledR}$ (https://www.scharlab. com, Cat No. ET0002025P).

- Silicon dioxide (https://www.fishersci.se, Cat No. S5631-500G).

- Hydrochloric acid (https://www.sigmaaldrich.com, Cat No. H1758-500ML).

- Absolute Ethanol ExpertQ ${ }^{\circledR}$ (https://www.scharlab. com, Cat No. ET0002025P).

- Tris Base (https://www.itwreagents.com, Cat No. 14194.1211).

\section{Equipment}

- Qiagen TissueLyser II (https://www.qiagen.com, Cat No. 85300).

- Thermoblock (https://www.vwr.com, Cat No. 12621-096).

- Eppendorf Centrifuge 5424 (https://www.eppen dorf.com, Cat. No. 5404000010).

\section{Reagent setup}

Extraction buffer: 2\% (w/v) CTAB, 2\% (w/v) PVP40, $20 \mathrm{mM}$ EDTA, $100 \mathrm{mM}$ Tris $\mathrm{HCl}(\mathrm{pH} \mathrm{8.0)}$ and $1.40 \mathrm{M} \mathrm{NaCl}$. The buffer may be stored for several months at room temperature.

Protein precipitation buffer: 24 parts of chloroform and 1 part of isoamyl alcohol. It may be stored for several months at room temperature.

Binding buffer: $2.5 \mathrm{M} \mathrm{NaCl}$ and 20\% PEG 8000. It may be stored for several months at room temperature.

Silica matrix buffer: Mix $5 \mathrm{~g}$ of silicon dioxide with $50 \mathrm{ml}$ of MilliQ water and let stand for $24 \mathrm{~h}$. Discard the supernatant and resuspend the pellet in $50 \mathrm{ml}$ of MilliQ water and let stand for another $5 \mathrm{~h}$. Discard the supernatant and resuspend the pellet in 1:1 (v/v) MilliQ water. Finally, add $10 \mu \mathrm{l}$ of $\mathrm{HCl} 36 \%$ per $\mathrm{ml}$ of silica matrix solution obtained. It may be stored for several months at room temperature.

Washing buffer: Fresh prepared ethanol 70\%. It may be stored for several months at room temperature. Elution buffer: $10 \mathrm{mM}$ Tris $\mathrm{HCl}(\mathrm{pH} 8.0)$ and $1 \mathrm{mM}$ EDTA ( $\mathrm{pH}$ 8.0). It may be stored for several months at room temperature.

\section{Protocol \\ SILEXDNA extraction protocol}

1. Add a $5 \mathrm{~mm}$ glass bead to a $2 \mathrm{ml}$ tube, place around $50 \mathrm{mg}$ of fresh or lyophilized tissue into the tube and immediately frozen in liquid nitrogen.

2. Place the tubes in the Qiagen TissueLyser adapters, grind the samples for 60 secs at 13,000 rpm and immediately return the samples in liquid nitrogen.

NOTE: This is a critical step and can greatly influences the final DNA recovery. Avoid sample thaw and pre-chill Qiagen TissueLyser plate adapters. Check that the plant material has become a fine powder.

3. Take the tube from the liquid nitrogen and gently tap it vertically to settle the plant material at the 
bottom of the tube. Add $1 \mathrm{ml}$ of extraction buffer, add $14 \mu \mathrm{l}$ of $\beta$-mercaptoethanol and gently mix the tube until complete homogenization. Then, add $2 \mu \mathrm{l}$ of RNase $(10 \mathrm{mg} / \mathrm{ml})$ and incubate in a thermoblock for $30 \mathrm{~min}$ at $65^{\circ} \mathrm{C}$.

NOTE: Avoid sample thaw before adding the extraction buffer. Preheat the thermoblock at $65^{\circ} \mathrm{C}$.

4. Put the samples on ice for $5 \mathrm{~min}$. Add $700 \mu \mathrm{l}$ of protein precipitation buffer and gently vortex or (for very high molecular weight DNA) gently invert by hand thoroughly for approximately $20 \mathrm{~s}$.

5. Centrifuge at $11,000 \mathrm{rpm}$ for $5 \mathrm{~min}$ at room temperature, carefully recover around $800 \mu \mathrm{l}$ of the supernatant phase and transfer it to a new $2 \mathrm{ml}$ tube.

NOTE: Pipette carefully to avoid dragging the interphase. Interphase contaminants can largely affect the final quality of the DNA.

6. Add $480 \mu \mathrm{l}$ of binding buffer and gently invert the tube by hand until complete mixing. Subsequently, add $720 \mu \mathrm{l}$ of absolute ethanol and gently invert the tube again for a few seconds until complete mixing.

NOTE: The amount of binding buffer plus ethanol must be 1.5 volumes of the supernatant recovered in step 5 . In the binding buffer plus ethanol mix, 40\% should be the binding buffer and $60 \%$ should be absolute ethanol.

7. Add $20 \mu \mathrm{l}$ of silica matrix buffer and mix gently during 5 min (by hand or using an orbital shaker).

8. Spin down the silica for 5 to $6 \mathrm{~s}$ and discard the supernatant by decantation.

NOTE: Longer centrifugation times will make it difficult to resuspend the silica in the subsequent steps.

9. Add $700 \mu \mathrm{l}$ of washing buffer and shake gently by hand until a uniform dispersion of the silica is obtained.

10. Spin down the silica for 5 to $6 \mathrm{~s}$, gently discard the supernatant by decantation and let dry at room temperature for $5 \mathrm{~min}$.

NOTE: Make sure that all ethanol is completely evaporated.

11. Add $100 \mu$ of elution buffer, shake gently by hand until the pellet is resuspended and incubate $5 \mathrm{~min}$ at $65^{\circ} \mathrm{C}$.

12. Centrifuge at $14,000 \mathrm{rpm}$ for $10 \mathrm{~min}$ at room temperature and transfer $90 \mu \mathrm{l}$ of the supernatant to a new tube.

\section{DNA concentration and quality}

DNA integrity was checked by electrophoresis on a $0.8 \%$ agarose gel (Condalab, Madrid, Spain) in $1 \mathrm{X}$ TAE buffer (GenoChem World, Valencia, Spain) stained with
GelRed $^{\circledR}$ (Biotium, Fremont, CA, USA) at a constant voltage of $100 \mathrm{~V}$ for $50 \mathrm{~min}$. Gel Doc XR + System transilluminator (Bio-Rad, Hercules, CA, USA) was used to visualized agarose gels. For high-molecular-weight DNA, the size and integrity were tested by pulse-field gel electrophoresis was run at $3.3 \mathrm{~V} / \mathrm{cm}$ in 15 -second cycles with an angle of $120^{\circ}$ for $24 \mathrm{~h}$ at $4{ }^{\circ} \mathrm{C}$ with $0.8 \%$ agarose in $\mathrm{TB}$ buffer.

DNA yield and quality were measured spectrophotometrically using NanoDrop ${ }^{\mathrm{TM}}$ ND-1000 (Thermo Scientific, Waltham, MA, USA). $\mathrm{A}_{260} / \mathrm{A}_{280}$ and $\mathrm{A}_{260} / \mathrm{A}_{230}$ ratios were measured to determine, respectively, protein and polysaccharide contamination. DNA quantity was also quantified with a $\mathrm{Qubit}^{\mathrm{TM}}$ 2.0. Fluorometer (Thermo Scientific, Waltham, MA, USA). An aliquot of $2 \mu$ of each sample was examined using the Qubit ${ }^{\mathrm{TM}}$ dsDNA BR Assay Kit (Thermo Scientific, Waltham, MA, USA) according to the instructions of the manufacturer.

In addition, the concentration of DNA obtained from the 1860 tomato samples was measured fluorometrically using Quant-iT ${ }^{\mathrm{TM}}$ PicoGreen $^{\mathrm{TM}}$ dsDNA Assay Kit (hereafter PicoGreen, Thermo Scientific, Waltham, MA, USA) and a 96-wells plate reader VICTOR3 1420 (PerkinElmer, Waltham, MA, USA) equipped with an excitation filter F485 and emission filter F535.

To check the suitability of the DNA extraction method for sequencing applications where DNA is fragmented, approximately $1 \mu \mathrm{g}$ of DNA was digested for $1 \mathrm{~h}$ at $37{ }^{\circ} \mathrm{C}$ followed by $20 \mathrm{~min}$ at $65{ }^{\circ} \mathrm{C}$ with restriction enzymes EcoRI (New England Biolabs, Ipswich, MA, USA). The digestion was evaluated through $1 \%$ agarose electrophoresis as above.

\section{High-throughput genotyping quality check}

For the first trial, sequencing of tomato samples for genotyping by SPET was performed with an Illumina NextSeq500 platform (Illumina Inc., San Diego, CA, USA), following the manufacturer protocol. Phred values were obtained using FastQC Version 0.11.8. and plotted in R [43] using the package ggplot2 [44].

\section{Suitability of extracted DNA for third-generation sequencing platforms}

For the third trial, $5 \mu \mathrm{g}$ of S. elaeagnifolium DNA from a single extraction were size-selected using the Circulomics SRE-XL-Kit (Circulomics Inc., Baltimore, MD, USA). For library preparation, $1 \mu \mathrm{g}$ of the size-selected DNA was used to prepare each of the three Nanopore LSK-109 libraries. Two of these libraries were sequenced on a MinION R9.4.1 (Oxford Nanopore, Oxford, UK) and the third was loaded on a PromethION PRO-002 (Oxford Nanopore, Oxford, UK). All three sequencing runs were basecalled using Oxford Nanopores Guppy basecaller 
version 3.2.2 (Oxford Nanopore, Oxford, UK) using the high accuracy basecalling models.

\section{Results}

Comparison of DNA extraction methods

Tomato leaf samples

Total DNA yield extracted through the SMP kit and estimated by NanoDrop ranged from $14.5 \mathrm{ng} / \mathrm{mg}$ to $366.9 \mathrm{ng} / \mathrm{mg}$ with a mean of $38.3 \mathrm{ng} / \mathrm{mg}$ and a standard deviation (SD) of $29.2 \mathrm{ng} / \mathrm{mg}$. DNA extracted by SILEX showed higher output, ranging from $86.1 \mathrm{ng} / \mathrm{mg}$ to $1698.1 \mathrm{ng} / \mathrm{mg}$ with an average of $382.9 \mathrm{ng} / \mathrm{mg}$ and a SD

Table 1 Mean value, standard deviation (SD), range and coefficient of variation (CV) of the DNA yield $(\mathrm{ng} / \mathrm{mg}$ ) using SILEX and SMP kit and quantified by NanoDrop (ND) and PicoGreen (PG)

\begin{tabular}{llllll}
\hline & \multicolumn{2}{l}{ SILEX } & & & \multicolumn{2}{l}{ SMP kit } \\
\cline { 2 - 3 } & ND & PG & & ND & PG \\
\hline Samples (n) & 1380 & & & 480 & \\
Mean & 382.9 & 141.3 & & 38.3 & 41.7 \\
SD & 205.3 & 36.8 & & 29.2 & 26.4 \\
Range & $86.1-1698.1$ & $37.9-231.2$ & & $14.5-366.9$ & $1.2-134.8$ \\
CV (\%) & 53.6 & 26.1 & & 76.1 & 63.4 \\
Ratio ND/PG & 2.7 & & 0.9 & \\
\hline
\end{tabular}

of $205.3 \mathrm{ng} / \mathrm{mg}$ (Table 1). Despite higher SD, the coefficient of variation (CV) of SILEX (53.6\%) was lower than that of the SMP kit (76.1\%).

The $A_{260} / A_{280}$ ratio, which indicates protein contamination, was very variable in the SMP kit protocol, ranging from 1.15 to 2.32, with an average of 1.76 and a SD of 0.33 (Fig. 1a). In contrast, SILEX showed a more consistent ratio with less variation (from 1.91 to 2.12) and with an average value of 2.03 and a SD of 0.05. Similarly, for the $A_{260} / A_{230}$ ratio, which indicates salt and carbohydrates contamination, SMP kit showed a greater dispersion, with a ratio between 0.27 and 2.43 with an average of 1.09 and a SD of 2.55 , compared to

Table 2 Mean value, standard deviation (SD), range and coefficient of variation (CV) of NanoDrop absorbance ratios $\left(A_{260} / A_{280}\right.$ and $\left.A_{260} / A_{230}\right)$ using SILEX and SMP kit

\begin{tabular}{llllll}
\hline & \multicolumn{2}{l}{ SILEX } & & & \multicolumn{2}{l}{ SMP kit } \\
\cline { 2 - 3 } & $\mathbf{A}_{\mathbf{2 6 0}} / \mathbf{A}_{\mathbf{2 8 0}}$ & $\mathbf{A}_{\mathbf{2 6 0}} / \mathbf{A}_{\mathbf{2 3 0}}$ & & $\mathbf{A}_{\mathbf{2 6 0}} / \mathbf{A}_{\mathbf{2 8 0}}$ & $\mathbf{A}_{\mathbf{2 6 0}} / \mathbf{A}_{\mathbf{2 3 0}}$ \\
\hline N samples & 1380 & & 480 & \\
Mean & 2.03 & 1.66 & & 1.76 & 1.17 \\
SD & 0.05 & 0.22 & 0.22 & 0.45 \\
Range & $1.91-2.12$ & $1.16-2.16$ & $1.15-2.32$ & $0.27-2.43$ \\
$\mathrm{CV}(\%)$ & 2.5 & 13.3 & 12.5 & 38.5 \\
\hline
\end{tabular}

$\mathrm{N}$ samples indicate the number of independent extractions performed
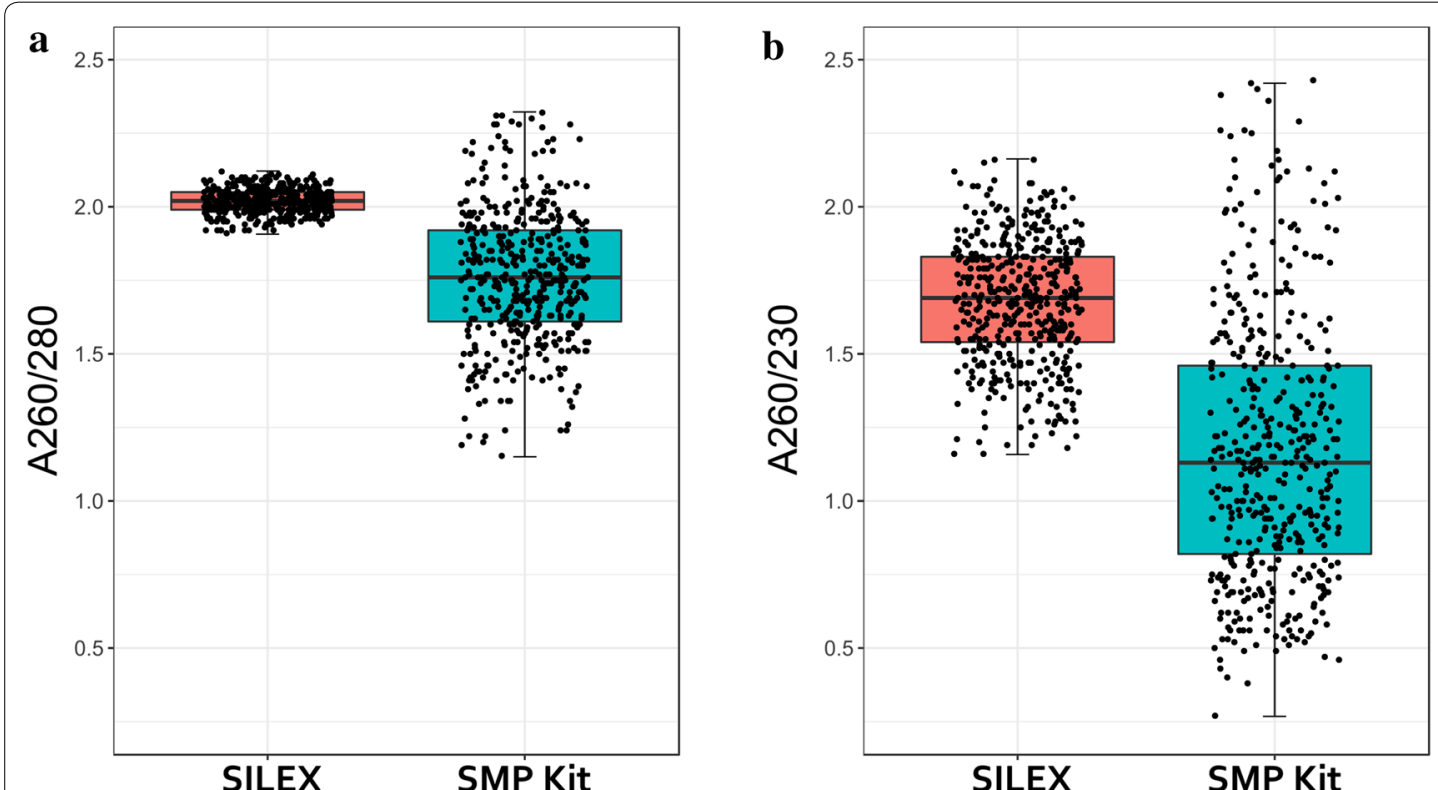

PROTOCOL

官 SILEX

宙 SMP Kit

Fig. 1 Quality control of DNA extracted with SILEX (orange) and SMP kit (blue) in 1380 and 480 tomato samples respectively. Box and whisker plots are based on $\mathbf{a} \mathrm{A}_{260} / \mathrm{A}_{280}$ and $\mathbf{b} \mathrm{A}_{260} / \mathrm{A}_{230}$. Each dot represents a sample, the median is indicated by a horizontal line, the box represents the upper and lower quartiles and the whiskers show the variability outside the quartiles." 
SILEX, which ranged from 1.16 to 2.16 with an average of 1.66 and a SD of 0.25 (Fig. 1b) (Table 2).

Since spectrophotometric measurements with NanoDrop tend to overestimate DNA yield due to likely interferences of proteins [45], those measures were compared with the fluorometric ones performed with PicoGreen. Yields estimated by the latter ranged from $1.2 \mathrm{ng} / \mathrm{mg}$ to $134.8 \mathrm{ng} / \mathrm{mg}$ with a mean of $41.7 \mathrm{ng} / \mathrm{mg}$ and a SD of $26.4 \mathrm{ng} / \mathrm{mg}$ in the case of DNA extracted by SMP kit. On the other hand, SILEX had higher yields, ranging from $37.9 \mathrm{ng} / \mathrm{mg}$ to $231.2 \mathrm{ng} / \mathrm{mg}$ with a mean of $141.3 \mathrm{ng} / \mathrm{mg}$ and a SD of $36.8 \mathrm{ng} / \mathrm{mg}$ (Table 1). In addition, yields estimated by PicoGreen had greater variation between samples in DNA extracted by SMP kit (63.4\%) in comparison with that extracted by SILEX (26.1\%).

To assess the overestimation of DNA yield extracted using the different protocols, we compared the ratios obtained by NanoDrop and PicoGreen measurements. Estimation of yield by NanoDrop of DNA extracted with the SMP kit showed an estimation of 0.9-fold compared to PicoGreen, suggesting that for this commercial kit NanoDrop measurements were comparable with the PicoGreen ones. In contrast, NanoDrop measurements from SILEX tended to overestimate DNA yield 2.7-fold compared to PicoGreen, suggesting contamination with a molecule absorbing at $260 \mathrm{~nm}$. One possible explanation for this overestimation is that remnants of degraded RNA were present in our samples, since nanodrop is unable to discriminate among free nucleotides, RNA, singlestranded DNA, and double-stranded DNA. However, even with this overestimation, the average yield obtained with SILEX (141.3 ng/mg with PicoGreen) was 3.4 times higher than with SMP kit (41.7 ng/mg).

\section{DNA extraction from dry and fresh fruit tissues}

The amount of DNA obtained from dry and fresh fruit tissues was similar to that achieved using leaf tissue and ranged from 116.4 to $920.3 \mathrm{ng} / \mathrm{mg}$. In general, higher yield of DNA was obtained with lyophilized tissue (Table 3). Regardless of the tissue used, $A_{260} / A_{280}$ ratios were above 2.0 which indicates no protein contamination. On the other hand, lower ratios were observed in $A_{260} / A_{230}$ ratio, suggesting the presence of some organic contaminants. Despite these ratios, DNA obtained was successfully digested by HindIII restriction enzyme.

Yield and quality control of DNA extracted by lyophilized and fresh fruit tissue of tomato, eggplant and pepper measured using NanoDrop.

\section{DNA extraction from recalcitrant species}

Overall, SILEX resulted in higher DNA yields, ranging (with fluorimetric determination) from $46.4 \mathrm{ng} / \mathrm{mg}$ in strawberry to $318.0 \mathrm{ng} / \mathrm{mg}$ in grapevine, than those
Table 3 Yield and quality control of DNA extracted by lyophilized and fresh fruit tissue of tomato, eggplant and pepper measured using NanoDrop. Mean value and standard deviation of 12 independent extractions are shown

\begin{tabular}{lllll}
\hline Species & Fruit sample & Yield $(\mathbf{n g} / \mathbf{m g})$ & \multicolumn{2}{c}{ Absorbance ratios } \\
\cline { 3 - 5 } & & & $\mathbf{A}_{\mathbf{2 6 0}} / \mathbf{A}_{\mathbf{2 8 0}}$ & $\mathbf{A}_{\mathbf{2 6 0}} / \mathbf{A}_{\mathbf{2 3 0}}$ \\
\hline \multirow{2}{*}{ Tomato } & Lyophilized & $116.4 \pm 65.3$ & $2.08 \pm 0.08$ & $1.30 \pm 0.11$ \\
& Fresh & $237.6 \pm 40.2$ & $2.22 \pm 0.04$ & $0.98 \pm 0.08$ \\
\multirow{2}{*}{ Eggplant } & Lyophilized & $863.0 \pm 289.0$ & $2.10 \pm 0.05$ & $1.36 \pm 0.13$ \\
& Fresh & $253.0 \pm 63.8$ & $2.11 \pm 0.04$ & $1.38 \pm 0.06$ \\
\multirow{2}{*}{ Pepper } & Lyophilized & $920.3 \pm 248.7$ & $2.10 \pm 0.04$ & $1.46 \pm 0.14$ \\
& Fresh & $271.6 \pm 54.0$ & $2.08 \pm 0.03$ & $1.18 \pm 0.15$ \\
\hline
\end{tabular}

obtained with the standard CTAB method or the SMP kit (Table 4). In addition, $A_{260} / A_{280}$ ratios obtained with SILEX were above 2.0, which is considered a protein-free DNA, except in strawberry where values were on average 1.86, even though they were higher than in standard CTAB and SMP kit. In the same way, SILEX $A_{260} / A_{230}$ ratios were higher than in the two other protocols, from 1.71 in loquat to 2.16 in banana, except in strawberry, where the results were similar to standard CTAB and SMP kit (Table 4). The differences were very noticeable in banana and grapevine, where the $\mathrm{A}_{260} / \mathrm{A}_{230}$ ratios were 2.7 and 4.3-fold lower for standard CTAB and 1.7 and 3.3-fold lower for SMP kit, respectively (Table 4). NanoDrop/Qubit ratio estimated with SILEX for recalcitrant species seemed to be species-dependent, and ranged from 1.4-fold in grapevine to 6.6-fold in naranjillo with a mean of 3.9-fold in comparison to Qubit. However, even though the SMP kit provided lower NanoDrop/Qubit ratios, SILEX performed better than the standard CTAB, which on average had a NanoDrop/Qubit ratio of 18-fold.

In order to test if the presence of contaminants could inhibit the enzyme activity, DNA was digested with the restriction enzyme EcoRI. Agarose gels, such as the one shown in Fig. 2 indicated efficient endonuclease activity in all the DNA extracted from the six recalcitrant species even though in some cases $A_{260} / A_{230}$ ratios were below 1.8 (strawberry and loquat). Also, strawberry samples showed yellow and brown coloration and high viscosity even after two washing steps.

\section{SILEX timing and cost}

The time needed to extract 48 samples, without taking into account the sampling of the plant material) is approximately $96 \mathrm{~min}$ (around $2 \mathrm{~min} / \mathrm{sample}$; Fig. 3). The estimated cost of all consumables required to extract high-molecular-weight gDNA using SILEX is 
Table 4 Yield and quality control of DNA extracted from six recalcitrant species using three different methods: SILEX, standard CTAB, and SMP kit quantified by NanoDrop (ND) and Qubit (Q)

\begin{tabular}{|c|c|c|c|c|c|}
\hline \multirow[t]{2}{*}{ Species/Methods } & \multicolumn{2}{|l|}{ Yield (ng/mg) } & \multicolumn{2}{|c|}{ Absorbance ratios } & \multirow[t]{2}{*}{ Ratio ND/C } \\
\hline & ND & Q & $A_{260} / A_{280}$ & $A_{260} / A_{230}$ & \\
\hline \multicolumn{6}{|l|}{ Cassava } \\
\hline SILEX & $556.0 \pm 76.6$ & $106.9 \pm 17.4$ & $2.04 \pm 0.02$ & $2.13 \pm 0.05$ & 5.3 \\
\hline CTAB & $512.7 \pm 61.1$ & $37.7 \pm 27.7$ & $2.12 \pm 0.02$ & $1.96 \pm 009$ & 13.6 \\
\hline SMP kit & $75.4 \pm 9.4$ & $85.5 \pm 13.9$ & $1.80 \pm 0.09$ & $1.44 \pm 0.10$ & 0.9 \\
\hline \multicolumn{6}{|l|}{ Grapevine } \\
\hline SILEX & $442.8 \pm 24.1$ & $318.0 \pm 115.2$ & $2.07 \pm 0.02$ & $1.93 \pm 0.01$ & 1.4 \\
\hline CTAB & $394.3 \pm 18.7$ & $21.5 \pm 6.1$ & $1.60 \pm 0.05$ & $0.44 \pm 0.03$ & 18.4 \\
\hline SMP kit & $50.7 \pm 30.2$ & $0.0 \pm 0.0$ & $1.73 \pm 0.20$ & $1.09 \pm 0.09$ & $\infty$ \\
\hline \multicolumn{6}{|l|}{ Loquat } \\
\hline SILEX & $284.4 \pm 24.9$ & $92.7 \pm 35.5$ & $2.02 \pm 0.05$ & $1.71 \pm 0.06$ & 3.1 \\
\hline CTAB & $112.7 \pm 7.5$ & $4.3 \pm 2.1$ & $1.58 \pm 0.17$ & $0.57 \pm 0.08$ & 25.9 \\
\hline SMP kit & $66.7 \pm 36.0$ & $7.7 \pm 6.1$ & $1.78 \pm 0.25$ & $1.15 \pm 0.41$ & 8.6 \\
\hline \multicolumn{6}{|l|}{ Banana } \\
\hline SILEX & $267.8 \pm 5.1$ & $59.2 \pm 8.2$ & $2.13 \pm 0.01$ & $2.16 \pm 0.05$ & 4.5 \\
\hline CTAB & $202.0 \pm 37.5$ & $19.1 \pm 5.6$ & $2.20 \pm 0.14$ & $0.78 \pm 0.13$ & 10.6 \\
\hline SMP kit & $31.4 \pm 37.5$ & $1.3 \pm 2.3$ & $1.47 \pm 0.31$ & $0.74 \pm 0.32$ & 23.3 \\
\hline \multicolumn{6}{|l|}{ Naranjillo } \\
\hline SILEX & $1184.1 \pm 484.3$ & $180.4 \pm 60.6$ & $2.06 \pm 0.02$ & $1.85 \pm 0.03$ & 6,6 \\
\hline CTAB & $525.4 \pm 126.2$ & $26.0 \pm 7.7$ & $1.91 \pm 0.11$ & $0.86 \pm 0.20$ & 20.2 \\
\hline SMP kit & $105.4 \pm 35.8$ & $42.6 \pm 19.8$ & $1.82 \pm 0.04$ & $1.72 \pm 0.07$ & 2.5 \\
\hline \multicolumn{6}{|l|}{ Strawberry } \\
\hline SILEX & $193.8 \pm 5.1$ & $46.4 \pm 6.1$ & $1.86 \pm 0.05$ & $1.02 \pm 0.08$ & 4.2 \\
\hline CTAB & $405.3 \pm 108.5$ & $24.6 \pm 4.0$ & $1.77 \pm 0.08$ & $1.14 \pm 0.11$ & 16.5 \\
\hline SMP kit & $25.9 \pm 2.8$ & $20.0 \pm 14.3$ & $1.69 \pm 0.16$ & $0.97 \pm 0.02$ & 1.3 \\
\hline
\end{tabular}

Ratios of the latter are reported. Mean value and standard deviation are based on a minimum of three independent extractions

approximately $0.12 €$ per sample (Additional file 1: Additional data S1).

\section{High-throughput genotyping platforms}

In order to evaluate the suitability of the gDNA obtained with SILEX for high-throughput genotyping, 1380 tomato samples were genotyped using SPET [6]. The reads obtained showed excellent Phred-quality scores along the $150 \mathrm{bp}$, with a mean value of 33.1 (Fig. 4). Similar results were obtained with 480 samples extracted using the SMP kit with a mean value of 33.5. The mean Phred score along the $150 \mathrm{bp}$ sequenced was always over 30 , indicating good sequencing quality in both methods, with the SILEX method providing more DNA per equal amount of tissue.

\section{High molecular weight DNA extraction}

To test the suitability of using SILEX for NGS platforms requiring high-molecular-weight DNA, S. elaeagnifolium DNA was size-selected using the Circulomics short read eliminator kit, recovering $3.5 \mu \mathrm{g}$, and analysed using
Pulsed-field gel electrophoresis (PFGE) (Fig. 5). The sizeselected DNA ranged from 20 to $100 \mathrm{~Kb}$ and contained relatively little small fragments. The sizes obtained were suitable for most sequencing platforms that require high molecular weight DNA free of impurities such as Nanopore or PacBio. Two libraries were sequenced with a MinION sequencer and yielded 6.8 and $7.5 \mathrm{Gbp}$, with N50 values of 22.8 and $28.2 \mathrm{kbp}$, respectively, while the third library, sequenced with a PromethION sequencer, resulted in $55.7 \mathrm{Gbp}$ of raw data with N50 of $24.2 \mathrm{kbp}$. After the base-calling, the total sequencing yield was 70.1 Gbp.

\section{Discussion}

One of the main advantages of the SILEX protocol for DNA extraction is the use of common and inexpensive reagents and its simplicity. No toxic salts such as guanidinium thiocyanate or sodium iodide at high concentrations are used. Several authors reported that the use of $\mathrm{NaCl}$ at concentrations higher than $2 \mathrm{M}$ facilitated the DNA binding to the silica surface [46-48]. Also, it 


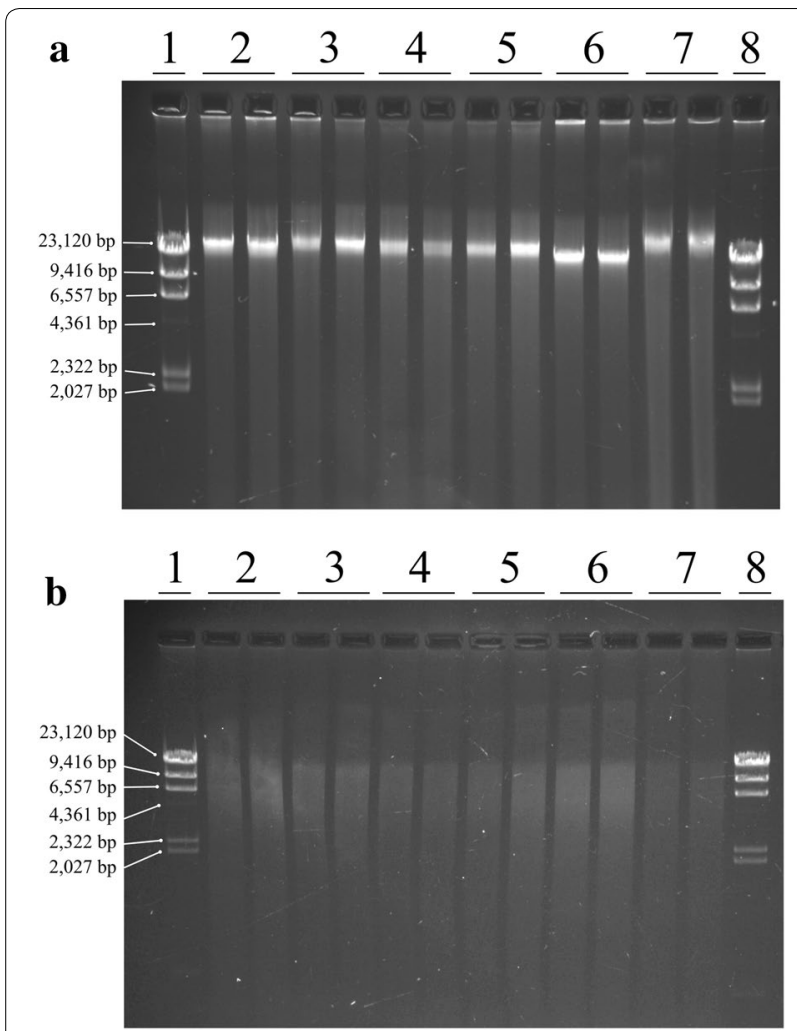

Fig. 2 Agarose gel electrophoresis of uncut genomic DNA extracted from six recalcitrant species with SILEX (a) and the same DNA cut with EcoRl enzyme (b). Two biological replicates for each species are shown. Lambda DNA restricted with Hindlll (lane 1 and 8); cassava (lane 2); grapevine (lane 3); loquat (lane 4); banana (lane 5); naranjillo (lane 6) and strawberry (lane 7)

is known that the addition of polyethylene glycol (PEG) to the binding solution increases the adsorption due to the compact globular structure of DNA adopted under these conditions [49]. For these reasons, we use a binding buffer composed by the non-toxic, inexpensive $\mathrm{NaCl}$ and PEG compound to facilitate the DNA binding to the silica surface. The total cost of reagents and consumables is only $0.12 €$ per sample and for multiple simultaneous manual extractions, each sample requires less than 2 min per person. In this respect, in the SILEX method, the silica matrix used for each extraction cost less than $0.001 €$ and the washing buffer is only water and ethanol, a common non-toxic reagent in most molecular biology laboratories.

The protocol presented here has been tested on many samples of different species with similar satisfactory results, confirming its wide applicability. The quality and quantity parameters obtained also indicate that SILEX is at least as effective as commercial kits even when recalcitrant species were used. In recalcitrant species, the presence of polysaccharides and

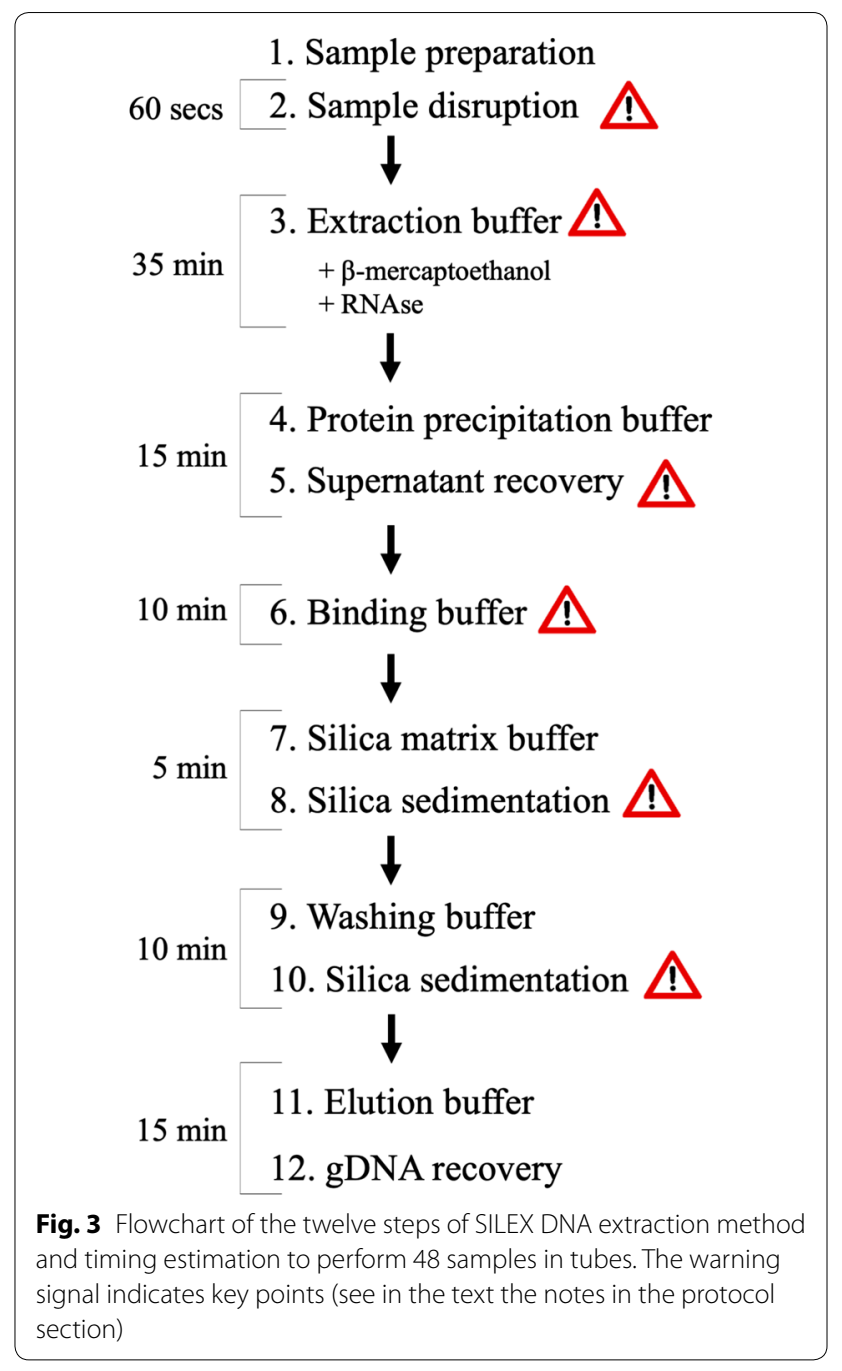

phenols was significantly lower in SILEX compared to the standard CTAB protocol where several samples showed yellow and brown coloration and high viscosity, indicating the presence of oxidized polyphenols and high concentration of polysaccharides. One of the reasons for this difference could be the absence of a precipitation step in SILEX, as polysaccharides and polyphenols tend to co-precipitate with DNA when isopropanol or ethanol is added [50]. This is important since the presence of polysaccharides such as carrageenan, pectin and xylan are strong inhibitors of PCR $[51,52]$. We also observed that in species with very high polyphenol and polysaccharide compounds, such as strawberry [53], a second washing step increases the $\mathrm{A}_{260} / \mathrm{A}_{230}$ ratio. Our DNA extraction protocol has been tested by other research groups and it has been found to provide high-quality DNA in high concentrations in other plant species as different as silver fir (Abies alba), watermelon (Citrullus lanatus), melon (Cucumis melo), 


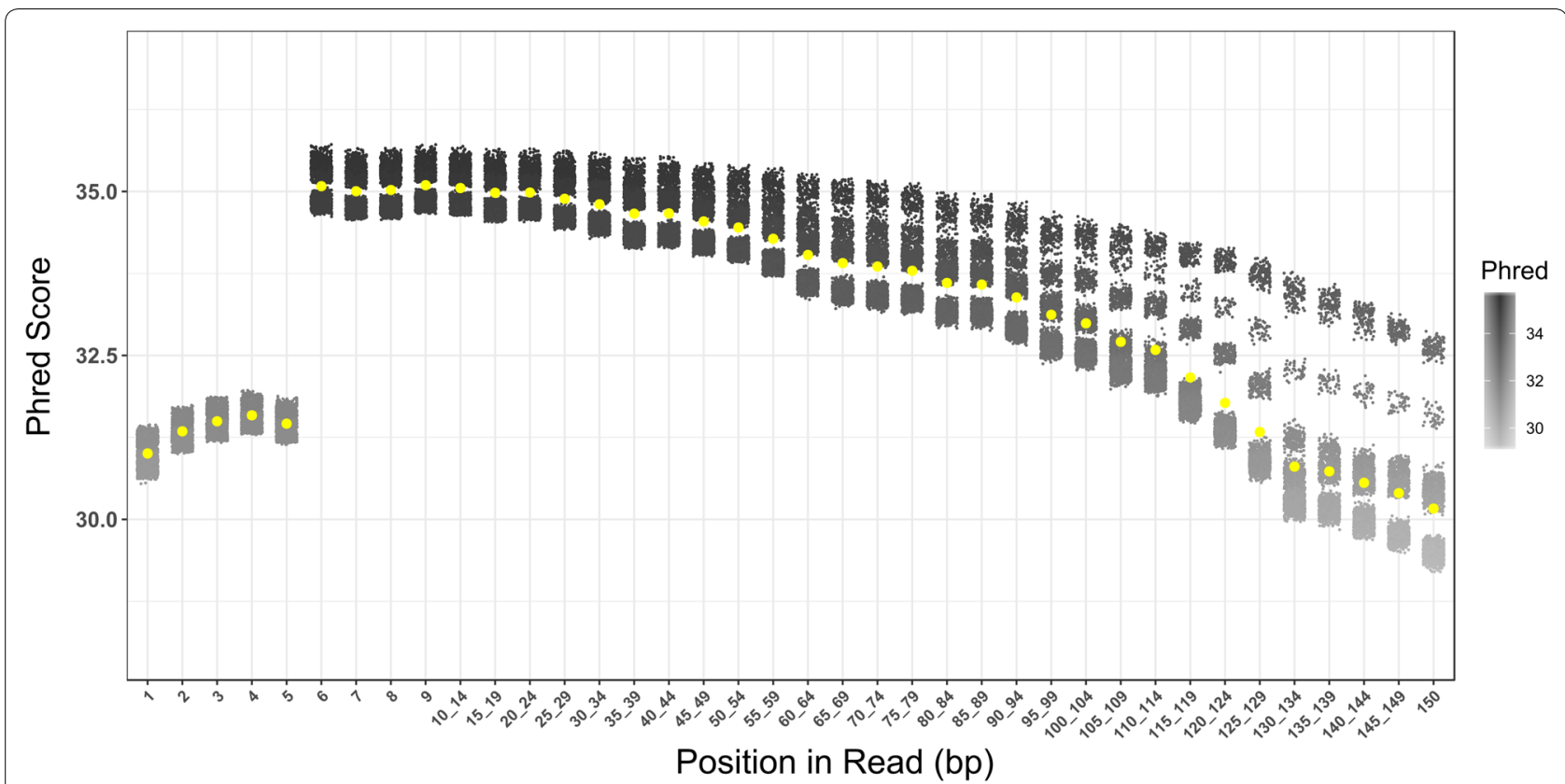

Fig. 4 Summary of Phred values for 1380 tomato samples extracted with the SILEX protocol and genotyped with SPET along the 150 bp sequence. Each dot corresponds to one sample. Yellow spots indicate the mean value

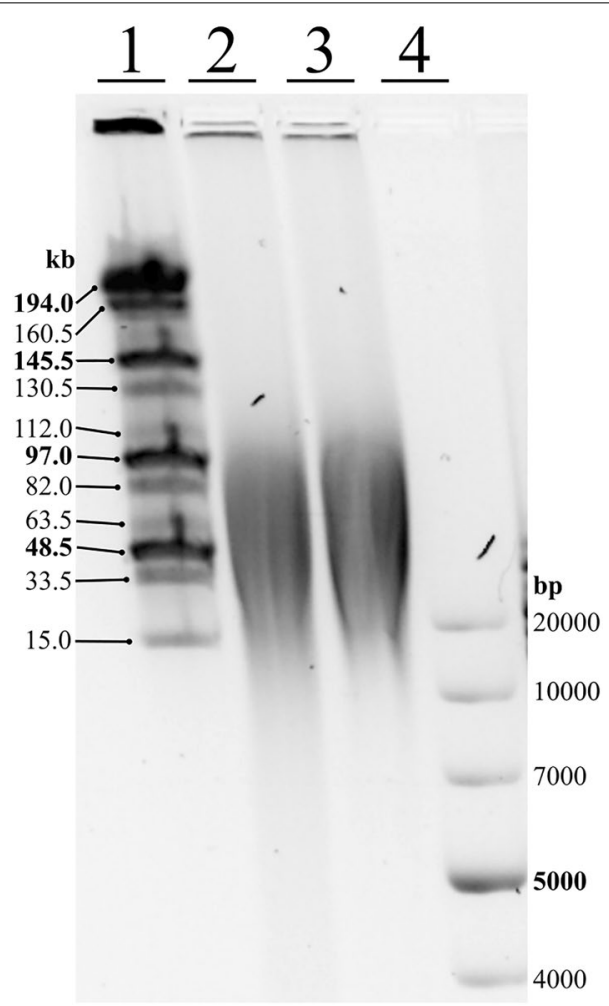

Fig. 5 Solanum elaeagnifolium gDNA size estimation using PFGE after extraction with SILEX. Line 1 is MidRange PFG Marker (New England Biolabs, Ipswich, USA) and line 4 is GeneRuler 1 kb Plus DNA (Thermo Fisher Scientific, Waltham, USA). Line 2 shows the gDNA before size selection and line 3 the gDNA before size selection after using Short Read Eliminator XL Kit summer squash (Cucumis pepo), common fig (Ficus carica), lettuce (Lactuca sativa), European larch (Larix decidua), Spanish stonecrop (Sedum hispanicum), avocado (Persea americana) and sweet cherry (Prunus avium). Applications have included genotyping by SSRs (Single Sequence Repeats), HRM (High-Resolution Melting), and GBS among others.

Although DNA is usually extracted from fresh leaf tissue, it is sometimes necessary to use other types of material such as fresh or freeze-dried fruit. Our protocol was flexible enough to successfully extract high DNA quantities from lyophilized and fresh fruit tissues obtaining $\mathrm{A}_{260} / \mathrm{A}_{280}$ ratios above 2.0.

Thousands of samples of tomato and wild relatives were successfully genotyped using SPET high-throughput genotyping, that relays on DNA fragmentation, target probe annealing, PCR amplification and NGS sequencing [6]. The quality of the reads produced had a mean Phred value over 30, which represents a base call accuracy of $99.9 \%$. Also, hundreds of samples of grapevine and watermelon were genotyped using GBS, obtaining similar results (C. Esteras, personal communication). This indicates the suitability of SILEX to yield DNA of enough quality to be used in different genotyping platforms. Furthermore, our DNA extraction method could be used in applications requiring high molecular weight genomic DNA, such as long-read single molecule Nanopore sequencing [54] without any additional steps. 


\section{Conclusions}

The SILEX protocol presented here is very robust and can be used in a wide variety of plants (including recalcitrant ones) and several tissues. It is based on common reagents without the need of expensive salts or equipment. This makes it inexpensive ( $0.12 €$ of reagents and consumables per sample) and accessible to most laboratories. It is also a fast method, where a trained person could process up to 48 samples in 96 min using Eppendorf tubes or $192 \mathrm{~min}$ if the extraction is performed in 96-well plates. The protocol is also amenable to automatization specially in labs that already have automatic DNA extraction robots. This could save hands-on time and increase the number of samples processed per day. We demonstrate that this new method gathers the advantages of commercial kits (high-quality DNA, fast and broad species spectrum) with those of the CTAB-based method (high yield and inexpensive), being suitable for routine DNA extraction for multiple applications, including NGS platforms.

\section{Supplementary information}

Supplementary information accompanies this paper at https://doi. org/10.1186/s13007-020-00652-y.

Additional file 1. Detailed cost per sample extracted for all solutions, reagents and consumables used for SILEX workflow.

\section{Authors' contributions}

SV conceptualized the study and developed the protocol. SV, DA, PG, EG and MP optimized the protocol. DA extracted tomato samples and PF and GG performed SPET genotyping. MS and BU performed Nanopore sequencing. DA, EG and MP performed the rest of extractions. MJD, BU, GG and JP supervised the study and provided resources. SV, DA, PG, MP, PF, MS, MJD and JP analyzed the data. SV, DA, PG and JP wrote the manuscript draft. All authors read and approved the final manuscript.

\section{Funding}

This research has been funded by the European Union's Horizon 2020 research and innovation programme under grant agreement No 677379 (Linking genetic resources, genomes and phenotypes of Solanaceous crops; G2P-SOL). David Alonso is grateful to Universitat Politècnica de València for a predoctoral (PAID-01-16) contract under the Programa de Ayudas de Investigación y Desarrollo initiative. Mariola Plazas is grateful to Generalitat Valenciana and Fondo Social Europeo for a postdoctoral grant (APOSTD/2018/014). Pietro Gramazio is grateful to Japan Society for the Promotion of Science for a Postdoctoral Grant (P19105, FY2019 JSPS Postdoctoral Fellowship for Research in Japan (Standard)). The Spanish Ministerio de Educación, Cultura y Deporte funded a predoctoral fellowship granted to Edgar García-Fortea (FPU17/02389).

\section{Availability of data and materials}

The datasets used and/or analysed during the current study are available from the corresponding author on reasonable request.

\section{Ethics approval and consent to participate}

Not applicable.

\section{Consent for publication}

Not applicable.

\section{Competing interests}

The authors declare that they have no competing interests.

\section{Author details}

${ }^{1}$ Instituto de Conservación y Mejora de la Agrodiversidad Valenciana, Universitat Politècnica de València, Camino de Vera 14, 46022 Valencia, Spain. ${ }^{2}$ Faculty of Life and Environmental Sciences, University of Tsukuba, 1-1-1 Tennodai, 305-8572 Tsukuba, Japan. ${ }^{3}$ ENEA, Italian National Agency for New Technologies, Energy and Sustainable Economic Development, Rome, Italy. ${ }^{4}$ BG-4 Bioinformatics, Forschungszentrum Jülich, 52428 Jülich, Germany. ${ }^{5}$ CEPLAS, Institute for Biological Data Science, Heinrich Heine University Düsseldorf, 40225 Düsselforf, Germany.

Received: 15 May 2020 Accepted: 3 August 2020

Published online: 10 August 2020

\section{References}

1. Scheben A, Batley J, Edwards D. Genotyping-by-sequencing approaches to characterize crop genomes: choosing the right tool for the right application. Plant Biotechnol J. 2017;15:149-61.

2. Jung $H$, Winefield $C$, Bombarely A, Prentis P, Waterhouse P. Tools and strategies for long-read sequencing and de novo assembly of plant genomes. Trends Plant Sci. 2019;24:700-24.

3. Elshire RJ, Glaubitz JC, Sun Q, Poland JA, Kawamoto K, Buckler ES, Mitchell SE. A robust, simple genotyping-by-sequencing (GBS) approach for high diversity species. PLOS ONE. 2011;6:e19379.

4. Baird NA, Etter PD, Atwood TS, Currey MC, Shiver AL, Lewis ZA, Selker EU, Cresko WA, Johnson EA. Rapid SNP discovery and genetic mapping using sequenced RAD markers. PLoS ONE. 2008;3:e3376.

5. Scaglione D, Pinosio S, Marroni F, Centa E, Fornasiero A, Magris G, Scalabrin S, Cattonaro F, Taylor G, Morgante M. Single primer enrichment technology as a tool for massive genotyping: a benchmark on black poplar and maize. Ann Bot. 2019;124:543-51.

6. Barchi L, Acquadro A, Alonso D, Aprea G, Bassolino L, Demurtas O, Ferrante P, Gramazio P, Mini P, Portis E, Scaglione D, Toppino L, Vilanova S, Díez MJ, Rotino G, Lanteri S, Prohens J, Giuliano G. Single primer enrichment technology (SPET) for high-throughput genotyping in tomato and eggplant germplasm. Front Plant Sci. 2019;10:1005.

7. Vaillancourt B, Buell CR. High molecular weight DNA isolation method from diverse plant species for use with Oxford Nanopore sequencing. bioRxiv. 2019;1:783159.

8. Anderson CB, Franzmayr BK, Hong SW, Larking AC, van Stijn TC, Tan R, Moraga R, Faville M, Griffiths A. Protocol: a versatile, inexpensive, high-throughput plant genomic DNA extraction method suitable for genotyping-by-sequencing. Plant Methods. 2018;14:75.

9. Rana MM, Aycan M, Takamatsu T, Kaneko K, Mitsui T, Itoh K. Optimized nuclear pellet method for extracting next-generation sequencing quality genomic DNA from fresh leaf tissue. Methods Protoc. 2019;2:54.

10. Doyle JJ, Doyle JL. Isolation of plant DNA from fresh tissue. Focus. 1990;12:13-5.

11. Healey A, Furtado A, Cooper T, Henry RJ. Protocol: a simple method for extracting next-generation sequencing quality genomic DNA from recalcitrant plant species. Plant Methods. 2014;10:21.

12. Martínez-González CR, Ramírez-Mendoza R, Jiménez-Ramírez J, GallegosVázquez C, Luna-Vega I. Improved method for genomic DNA extraction for Opuntia Mill. (Cactaceae). Plant Methods. 2017;13:82.

13. Barbier FF, Chabikwa TG, Ahsan MU, Cook SE, Powell R, Tanurdzic M, Beveridge $C$. A phenol/chloroform-free method to extract nucleic acids from recalcitrant, woody tropical species for gene expression and sequencing. Plant Methods. 2019;15:62.

14. Souza DC, Teixeira TA. A simple and effective method to obtain high DNA quality and quantity from Cerrado plant species. Mol Biol Rep. 2019:46:4611-5.

15. Kovačević N. Magnetic beads based nucleic acid purification for molecular biology applications. Sample preparation techniques for soil, plant, and animal samples. In: Micic M, editor. Springer Protoc Handb. 2016;53-67.

16. Martin SL, Parent JS, Laforest M, Page E, Kreiner JM, James T. Population genomic approaches for weed science. Plants. 2019:8:354.

17. Zhou Y, Zhang Y, He W, Wang J, Peng F, Huang L, Zhao S, Deng W. Rapid regeneration and reuse of silica columns from PCR purification and gel extraction kits. Sci Rep. 2018;8:12870. 
18. Park HJ, Cho H, Jung HS, Cho BH, Lee MY. Development of a DNA isolation device using poly(3,4-dihydroxy-L-phenylalanine)-coated swab for on-site molecular diagnostics. Sci Rep. 2019;9:8144.

19. Boom R, Sol CJ, Salimans MM, Jansen CL, Wertheim-van Dillen PM, van der Noordaa J. Rapid and simple method for purification of nucleic acids. J Clin Microbiol. 1990;28:495-503.

20. Carter MJ, Milton ID. An inexpensive and simple method for DNA purifications on silica particles. Nucleic Acids Res. 1993;21:1044.

21. Carvalho J, Puertas G, Gaspar J, Azinheiro S, Diéguez L, Garrido-Maestu A, Vázquez M, Barros-Velázquez J, Cardoso S, Padro M. Highly efficient DNA extraction and purification from olive oil on a washable and reusable miniaturized device. Anal Chim Acta. 2018:1020:30-40.

22. Branton D, Deamer D, Quick J, Loman NJ. DNA extraction strategies for nanopore sequencing. Nanopore Seq. World Sci. 2019;1:91-105.

23. Cheng H, Zhang K, Libera J, De La Cruz M, Bedzyk M. Polynucleotide adsorption to negatively charged surfaces in divalent salt solutions. Biophys J. 2016;90:1164-74.

24. Shi B, Shin Y, Hassanali A, Singer S. DNA Binding to the Silica Surface. J Phys Chem B. 2015;119:11030-40.

25. Katevatis C, Fan A, Klapperich CM. Low concentration DNA extraction and recovery using a silica solid phase. PLoS ONE. 2017;12:e0176848.

26. Green MR, Sambrook J. Isolation and quantification of DNA. Cold Spring Harb Protoc. 2018;2018:403-14.

27. Toole K, Roffey P, Young E, Cho K, Shaw T, Smith M, Blagojevic N. Evaluation of commercial forensic DNA extraction kits for decontamination and extraction of DNA from biological samples contaminated with radionuclides. Forensic Sci Int. 2019:302:109867.

28. Piskata Z, Servusova E, Babak V, Nesvadbova M, Borilova G. The quality of DNA isolated from processed food and feed via different extraction procedures. Molecules. 2019;24:1188.

29. Xia Y, Chen F, Du Y, Liu C, Bu G, Xin Y, Boye L. A modified SDS-based DNA extraction method from raw soybean. Biosci Rep. 2019;39:2.

30. Akkurt M. Comparison between modified DNA extraction protocols and commercial isolation kits in grapevine (Vitis vinifera L.). Genet Mol Res. 2012:11:2343-51.

31. Marsal G, Baiges I, Canals JM, Zamora F, Fort F. A Fast, efficient method for extracting DNA from leaves, stems, and seeds of Vitis vinifera L. Am J Enol Vitic. 2011:62:376-81.

32. Abdel-Latif A, Osman G. Comparison of three genomic DNA extraction methods to obtain high DNA quality from maize. Plant Methods. 2017;13:1

33. Huang J, Ge X, Sun M. Modified CTAB protocol using a silica matrix for isolation of plant genomic DNA. Biotechniques. 2000;28:432-4.

34. Rogstad SH. Plant DNA extraction using silica. Plant Mol Biol Report. 2012;21:463.

35. Li J-F, Li L, Sheen J. Protocol: a rapid and economical procedure for purification of plasmid or plant DNA with diverse applications in plant biology. Plant Methods. 2010;6:1

36. Li J-F, Sheen J. DNA purification from multiple sources in plant research with homemade silica resins. Humana Press. 2012;862:53-9.

37. Vandeventer PE, Lin JS, Zwang TJ, Nadim A, Johal MS, Niemz A. Multiphasic DNA adsorption to silica surfaces under varying buffer, $\mathrm{pH}$, and ionic strength conditions. J Phys Chem B. 2012;116:5661-70.

38. Boesenberg-Smith KA, Pessarakli MM, Wolk DM. Assessment of DNA yield and purity: an overlooked detail of PCR troubleshooting. Clin Microbiol Newsl. 2012;34:1-6.

39. Emaus MN, Clark KD, Hinners P, Anderson JL. Preconcentration of DNA using magnetic ionic liquids that are compatible with real-time PCR for rapid nucleic acid quantification. Anal Bioanal Chem. 2018;410:4135-44.
40. Dumschott K, Schmidt MHW, Chawla HS, Snowdon R, Usadel B. Oxford Nanopore sequencing: new opportunities for plant genomics? J Exp Bot. 2020;eraa263

41. Knapp S, Sagona E, Carbonell AKZ, Chiarini F. A revision of the Solanum elaeagnifolium clade (Elaeagnifolium clade; subgenus Leptostemonum, Solanaceae). PhytoKeys. 2017;84:1-104.

42. García-Fortea E, Gramazio P, Vilanova S, Fita A, Mangino G, Villanueva G, Arrones A, Knapp S, Prohens J, Plazas M. First successful backcrossing towards eggplant (Solanum melongena) of a New World species, the silverleaf nightshade (S. elaeagnifolium), and characterization of interspecific hybrids and backcrosses. Sci Hort. 2019;246:563-73.

43. Ihaka R, Gentleman R. R: a language for data analysis and graphics. J Comput Graph Stat. 1996:5:3299-314.

44. Wickham H. ggplot2: Elegant graphics for data analysis. New York: Springer-Verlag; 2016.

45. Ponti G, Maccaferri M, Manfredini M, Kaleci S, Mandrioli M, Pellacani G, Ozben T, Depenni R, Bianchi G, Pirola G, Tomasi A. The value of fluorimetry (Qubit) and spectrophotometry (NanoDrop) in the quantification of cellfree DNA (cfDNA) in malignant melanoma and prostate cancer patients. Clin Chim Acta. 2018:479:14-9.

46. Lakshmi R, Baskar V, Ranga U. Extraction of superior-quality plasmid DNA by a combination of modified alkaline lysis and silica matrix. Anal Biochem. 1999:272:109-12.

47. Taylor Jl, Hurst CD, Davies MJ, Sachsinger N, Bruce IJ. Application of magnetite and silica-magnetite composites to the isolation of genomic DNA. J Chromatogr A. 2000;890:159-66.

48. Prodělalová J, Rittich B, Španová A, Petrová K, Beneš MJ. Isolation of genomic DNA using magnetic cobalt ferrite and silica particles. J Chromatogr A. 2004;1056:43-8.

49. Shan Z, Jiang Y, Guo M, Bennett JC, Li X, Tian H, Oakes K, Zhang, Zhou Y, Huang Q, Chen $\mathrm{H}$. Promoting DNA loading on magnetic nanoparticles using a DNA condensation strategy. Colloids Surfaces B Biointerfaces. 2015;125:247-54.

50. Greco M, Sáez C, Brown M, Bitonti M. A simple and effective method for high quality co-extraction of genomic DNA and total RNA from low biomass Ectocarpus siliculosus, the model brown alga. PLoS ONE. 2014;9:e96470.

51. Schrader C, Schielke A, Ellerbroek L, Johne R. PCR inhibitor - occurrence, properties and removal. J Appl Microbiol. 2012;113:1014-26.

52. Demeke T, Adams RP. The effects of plant polysaccharides and buffer additives on PCR. Biotechniques. 1992;12:332-4.

53. Asami DK, Hong YJ, Barrett DM, Mitchell AE Comparison of the total phenolic and ascorbic acid content of freeze-dried and air-dried marionberry, strawberry, and corn grown using conventional, organic, and sustainable agricultural practices. J Agric Food Chem. 2003;51:1237-41.

54. Schmidt $M$, Vogel $A$, Denton $A$, Istace $B$, Wormit $A$, van de Geest $H$, Bolger M, Alseekh S, Maß J, Pfaff C, Schurr U, Chetelat R, Maumus F, Aury J, Koren S, Fernie A, Zamir D, Bolger A, Usadel B. De novo assembly of a new Solanum pennellii accession using nanopore sequencing. Plant cell. 2017;29:2336-48

\section{Publisher's Note}

Springer Nature remains neutral with regard to jurisdictional claims in published maps and institutional affiliations. 